\section{From the Beautiful} to the Bland

\section{Amazing Treasures at the Library of Congress}

JOYCE LAIOSA AND STEPHANIE BANGE



Title page of $A B C$ : Ein geschütteltes, geknütteltes Alphabet in Bildern mit Versen ( $A B C$ : A Nonsense Alphabet in Pictures with Verses) by Londa and Conrad FelixMüller (Germany, 1925). All photos taken with permission of the Library of Congress.

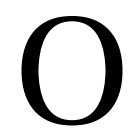
rganized by ALSC's Special Collections and Bechtel Fellowship Committee, a group of eight guests were treated to a presentation of some of the rare wonders for children at the Library of Congress (LC) while in Washington, DC, for the 2019 American Library Association (ALA) Annual Conference.

Our guide was Dr. Sybille A. Jagusch, chief, Children's Literature Center in the Rare Book and Special Collections Division. She manages the collection of 600,000 children's items, acquires and purchases items for the collection, arranges lectures, plans and executes exhibitions with printed guides in many cases, and is open to sharing (as she did for us) delightful items that were once handled by children from the United States as well as the rest of the world.

Sprinkled throughout our presentation, Jagusch spent time explaining some of the acquisition/collection policy guiding her choices for the collection. The LC holds the premier research book collection of children's literature in this country. In the early days, children's books arrived in an unsystematic fashion, but after the Copyright Law of 1870 , children's books have come in a steady stream just like all other books. ${ }^{1}$

There are a number of special collections. For example, early children's books are in the Rare Book and Special Collections Division; foreign language books are in other divisions. There are also items such as boxed and board games, sound recordings, maps, original children's book illustrations, books in Braille, books with CDs and other attachments, and books that move and make sounds. ${ }^{2}$
What makes the collection so unique is the fact that the collection is not selected. No one evaluates the content of a book. The collection holds everything from the beautiful to the bland, from the redundant to the controversial. All these books together make for a fine tableau of what Americans wrote and drew for their children. It contains all the dreams and hopes and the prejudices of a whole nation. ${ }^{3}$

"Acquisitions-both gifts and purchases-have become much more meaningful for me. When I select an item now I try to think not only of its research or exhibition value but how I might show it to visitors," said Jagusch. "People often ask me how I go about finding these special treasures. Dealers send
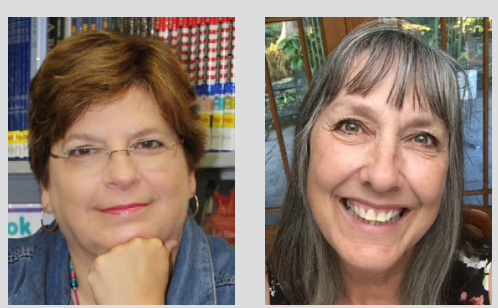

Joyce Laiosa is the retired Head of Youth and Family Services of Voorheesville (NY) Public Library. She has served in many capacities within ALSC and the New York Library Association. She is currently a member of the ALSC Bechtel/ Special Collections Committee. She also consults on early literacy programming, and has served as an instructor at the University at Albany. After thirty-eight years of working with children's literature in school, public, special, and academic libraries, Stephanie Bange decided to semi-retire and do consulting so she could continue to do her two favorite things: read children's books and travel. 
their catalogs to us, either the printed or the online version. I read those right away and if there is something of interest I call to reserve it. Then I do my research to see what the Library owns, in what edition, and so on. I also attend book fairs and sometimes visit a dealer's shop. Over the years, I have also accepted a number of book gifts. A rewarding experience."

What we didn't see is the LC's unparalleled secondary collection: the reference books, serials, etc., that researchers consult. The center answers reference questions from individual students, teachers, collectors, publishers, and others who study children's books. Presentations are made for congressional friends, families and constituents, student groups, book discussions clubs, and professional groups.

Her acquisition experiences include donations. One such incident was when James Marshall approached her at work and asked if she would be interested in his original art and book dummies. "Some things come here like that," Jagusch quietly said. As it turned out, he didn't have long to live.

Jagusch began with what is considered the first children's book published, an English/Latin copy of Orbis Sensualium Pictus: A World of Things Obvious to the Senses: Drawn in Pictures. Originally published in Latin and German in Nuremberg in 1658, it was quickly translated into English by Charles Hoole about 1660. In the book, the teacher shows the world to the child. It was a religious tool at the time and everything was "directed by God." (Note: The National Council of Teachers of English's Orbis Pictus Award is named after this book.)

The second item we viewed was more of a game than a book. Oxford Instructor is a set of ivory disks, each about two inches in diameter, with a letter of the alphabet on the obverse and a carved word and image that correlates with the letter on the reverse. Dating from the late eighteenth century, Jagusch remarked that it was "obviously used by a privileged child."

Next up was a rare "bookcase collection" written in French, housed in a wooden box with a sliding top that was constructed and painted to look like a miniature bookcase. This particular item included a complete set of books: a picture dictionary for an English child who was studying the French language. Its unusual shape made this an obvious choice for preservation to design and build a linen-covered, bookshaped storage box, with a pillow inside to support the top of the sliding top, as it extends over the edge of the box.

The group then admired a stunning "folded book" from the 1820s. When fully opened, this accordion-like book unfolded to show over twenty-five hand-colored illustrations of costume/dress from around the world. It is ironic that when the illustrator designed each costume, he did so without traveling to the countries to do research on their costumes/dress.

To balance this in the collection, Jagusch showed us a complete family/set of Chinese paper dolls from 1905. They were made in China and demonstrate what authentic Chinese



Book dummy of Floral Fairies: Adventures of Johnny Jump-up by Gertrude Robinson and illustrated by Alberta Hall, never published (1907).

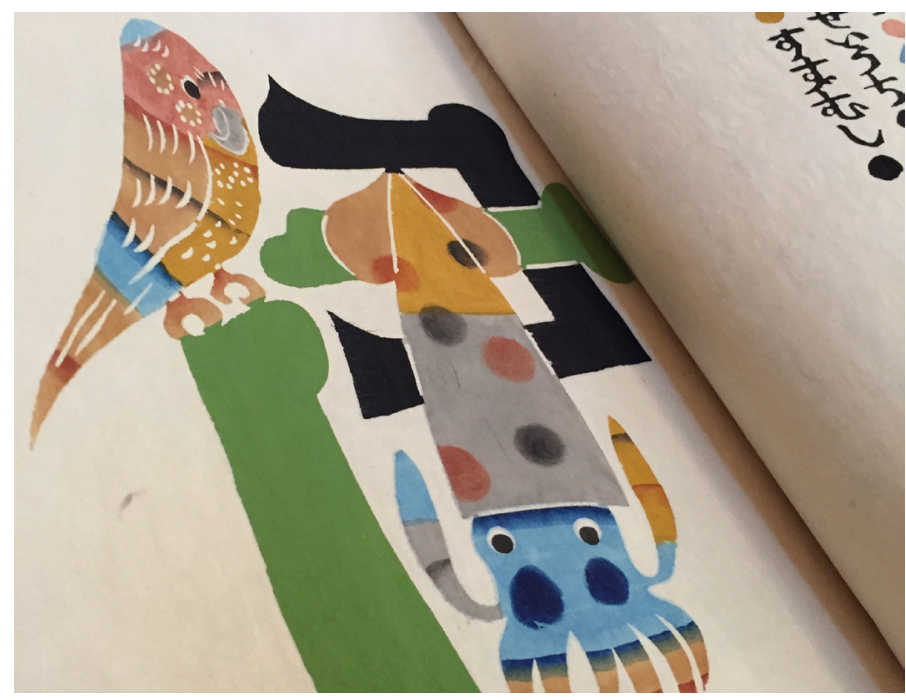

Hand-stenciled images of a bird and cuttlefish in an alphabettype book (Japan, circa 1930).

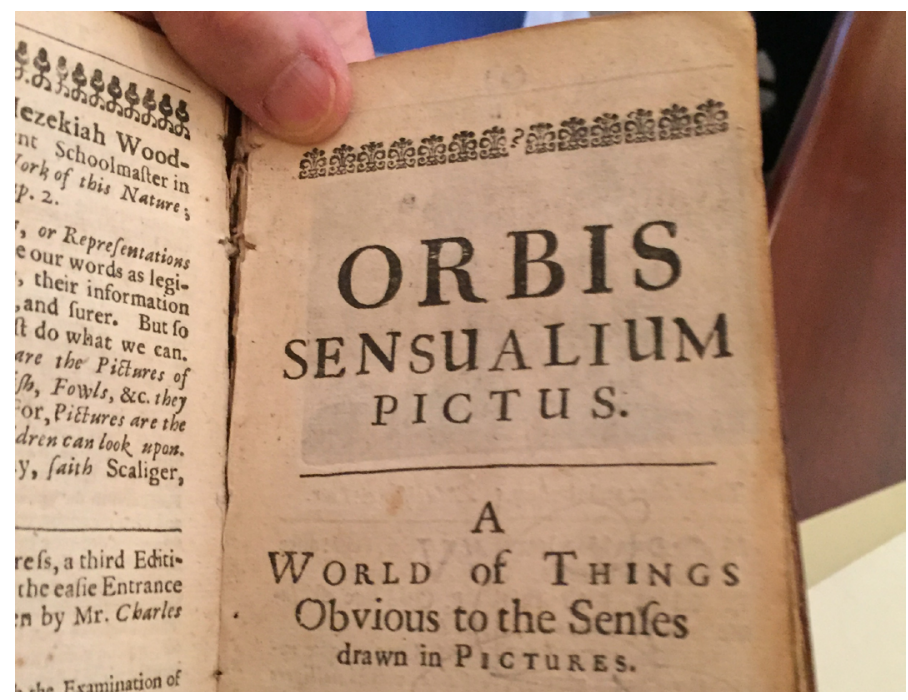

Title page of Orbis Sensualium Pictus: A World of Things Obvious to the Senses: Drawn in Pictures by Johann Amos Comenius, translated by Charles Hoole (London, 1658). 
costume/dress looked like at that time. It was intriguing to see each hand-painted paper doll assembled, and each had moveable parts, but the clothing that was also hand-painted had not been cut apart from the printed paper. When asked why this was added to the collection, Dr. Jagusch responded that while the importance of the authentic costume is first, the "whimsical" factor is also important.

We were dazzled to see one of just five remaining copies (numbered and signed) of a book by German Expressionist artist Conrad FelixMüller, ABC: Ein geschütteltes, geknütteltes Alphabet in Bildern mit Versen (ABC: A Nonsense Alphabet in Pictures with Verses). Most of FelixMüller's work was confiscated by the Nazis and burned or bombed during World War II. This is important for researchers studying the period.

Additional highlights included an undated original watercolor of Peter Rabbit inscribed to Anne Carroll Moore and signed by Beatrix Potter; an oversize Japanese book (circa 1930) of handmade paper that reads from left to right and features handpainted kanji text with intriguing animal illustrations done in stencil; a pristine copy of the German ABC book, Das Vogel $A B C$ by Friedrich Wilhelm Kleukens (circa 1920); a mockup book from 1905-10, Floral Fairies: Adventures of Johnny Jump-up by Gertrude Robinson and illustrated by Alberta Hall (it is unusual as Hall's original artwork and Robinson's typed text were tipped in on top of the pages of another picturebook; Floral Fairies was never published); two original illustrations by Alain Gauthier for Zizou, artichaut, coquelicot, oiseau (text by Jean Chalon); and two "paper

\section{References}

1. Kathryn Mendenhall, "Serving Those Who Serve Children-Kathryn Mendenhall and Sybille A. Jagusch: A Conversation,” Library of Congress, Library Services

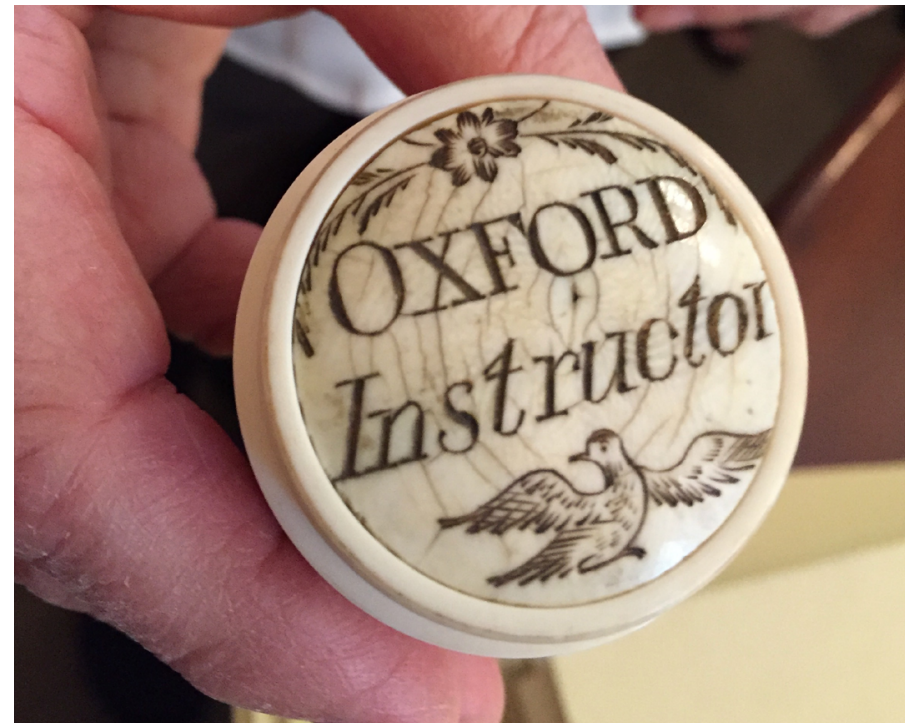

Box lid made of ivory for the learning game Oxford Instructor (undated).

theaters" (a scrolling picture in a box that tells a story), Panorama of The Visit of Santa Claus to the Happy Children and Un Voyage au Fond de la Mer.

After spending over an hour and a half, the group strongly agreed on two points-the Children's Literature Center at the Library of Congress is filled with many wondrous, magical treasures and that Dr. Jagusch is one of them. \&

Journal (Autumn 2010).

2. Mendenhall, "Serving Those Who Serve Children."

3. Mendenhall, "Serving Those Who Serve Children." 